\title{
Research on the Indian Capital Market: A Review
}

Samir K. Barua

V. Raghunathan

Jayanth R. Varma

Indian Institute of Management

Ahmedabad-380015

February 1994

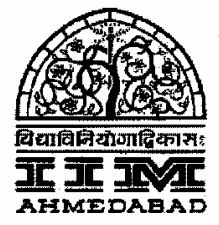




\title{
Research on the Indian Capital Market: A Review by
}

\author{
S.K. Barua, V. Raghunathan and J.R. Varma
}

\begin{abstract}
In this paper we present a review of research done in the field of Indian capital markets during the fifteen years from 1977 to 1992. The research works included in the survey were identified by two search procedures. Firstly, we wrote to 118 Indian university departments and research institutions requesting information on the works done in this field in their department/institution. After three reminders, we obtained responses from 53 institutions. Simultaneously, we searched through various Indian journals in our library, located books listed in the library catalogue and traced through the list of references provided in various research works.

Considering the size, vintage and development of the Indian capital market, the total volume of research on it appears to be woefully modest - about 0.1 unit of work per institution per year! Moreover, a large number of works are merely descriptive or prescriptive without rigorous analysis. Certain areas such as arbitrage pricing theory, option pricing theory, agency theory, and signalling theory are virtually unresearched in the Indian context. Besides, very little theoretical work has been done by researchers in India. However, with improved availability of databases and computing resources, and with increasing global interest in Indian markets, we expect an explosion of work in the near future.
\end{abstract}




\title{
Research on the Indian Capital Market: A Review ${ }^{1}$
}

\author{
- S.K. Barua, V. Raghunathan and J.R. Varma
}

A review paper on research done in any field invariably presents considerable difficulties. What comprises research? What should be the period of review? What should be the objective of a review? How does one ensure the coverage is comprehensive? It is clear that such questions as above are bound to generate varied answers. The difficulty of the task increases manifold in Indian conditions where institutional addresses are difficult to obtain at one place, ready bibliographies are rare, referencing in published research is hardly comprehensive, and reprints are difficult to obtain. We would therefore begin by briefly outlining the basis on which the review of research on Indian capital markets has been done in this paper.

\section{Research Definition}

It is not our objective to debate about what kind of work can be regarded as "research". For the purpose of the review, research has been defined as doctoral dissertations, papers published in academic journals, books (including expository, but excluding obviously popular books) and working papers or occasional unpublished papers (where such information was available) on Indian capital markets. We have not reviewed articles published in the popular media such as financial dailies, business magazines and other popular magazines and journals. We have also excluded dissertations for masters degrees, reports of government committees or commissions, seminar and conference papers. We have also largely excluded publications in foreign journals. It is possible that, in the process, the list of works reviewed may have excluded some excellent works published in popular media or included some sub-standard works published in academic journals. This narrowing of the coverage of the review on the above lines became necessary when we realized that it would be a truly Herculean task to include every kind of published and unpublished work on the Indian capital markets in and outside India.

\footnotetext{
${ }^{1}$ The authors are all members of finance faculty at the Indian Institute of Management, Ahmedabad. The authors gratefully acknowledge the able and painstaking research assistance provided by Ms. Lakshmi Ramanan. This work is partially supported by a research grant from the Indian Institute of Management, Ahmedabad.
} 


\section{Scope of Capital Market Research}

We were next faced with another difficult question about what can be classified as a work on capital markets. A variety of work in economics, accounting and finance would have some linkages with capital markets. Works in corporate finance have strong linkages with security markets. For our purpose therefore, we considered works falling into any of the following categories as those belonging to the field of capital markets: valuation of stocks and functioning of the stock markets; valuation of bonds, convertible debentures and market for debt; new issues market and merchant banking; market efficiency ; dividends, bonus \& rights issues and rates of return; and performance and regulations of mutual funds.

\section{Period of Review}

We have primarily reviewed work done in the fifteen years from 1977 to 1992 . In addition, some works published in 1993, which we could readily access while analyzing the data collected for the earlier fifteen years, have also been reviewed. It was not considered worthwhile to go further back in time because of two main reasons: a) the further one goes back in time, the more difficult it becomes to access works done, b) the characteristics of capital market in India have changed considerably and the market in the eighties and nineties has little resemblance with the market in the sixties and early seventies. We chose 1977 as a cut-off year for a break from the past since it was this year in which the MNCs operating in India were forced to dilute foreign holding under FERA. The dilution was perhaps the genesis of the equity cult which gave a fillip to the Indian capital market.

\section{Objective of Review}

Even this aspect of the review required resolution of some key issues. Should it simply consist of annotated bibliographies of the research? Should it be a commentary on the works done without drawing any inferences for the future, or should it be our assessment about the emerging scenario in the Indian capital market based on the research over the chosen period? We decided to provide a detailed bibliography at the end of the paper and provide a commentary on the more serious works in the main body of the paper. In several areas, particularly where there have been dramatic changes in the regulatory or operating environment, we have also identified the kind of research that is needed. 


\section{The Survey Process}

In order to ensure that the coverage was as exhaustive as possible, we wrote to 118 Indian university departments, institutes of management and other relevant autonomous research institutions in October 1992, requesting them to send us a list along with the abstracts of all the works (doctoral dissertations, published and unpublished papers in academic journals and books) done in the field of capital market and financial services in their department/institution. Financial services was included so as to ensure that areas such as mutual funds and merchant banking were not excluded from the response. We did not spell out any specific areas as we thought it best to let the respondents interpret research in capital market and financial services in its widest possible sense. We exercised our judgement on what work would qualify for inclusion under the area of capital market only after we received the responses.

In the first round, we received responses only from 9 departments/institutions. Subsequently, we sent three reminders, at intervals of one month each. The first reminder brought in 18 more responses; the second brought in another 13 and the third reminder 13 more responses, bringing the total number of respondents to 53. However, of these, only 28 institutions reported that some research had been done in the field of capital market and financial services by them.

Simultaneously, we started a search in the library of the Indian Institute of Management, Ahmedabad, for relevant information on research in Indian capital market. We searched through the contents of all Indian journals which could contain papers on capital markets and also located books listed in the library catalogue. The list of references provided at the end of papers were another source of tracing the works done in the area. As can be expected, we did face difficulties sometimes in locating papers because the particular volume in which the paper had appeared was missing, or that some new journal was not subscribet to by the library at all. Wherever we had information about the institute affiliation of the author/s, we wrote to the institute for a copy of the work or at least an abstract of the work.

The final list thus is the result of these two search procedures. However, despite our best efforts, abstracts of all works could not be obtained or prepared. In such cases the works have merely been listed in the bibliography and not commented upon in the paper.

The work compiled was categorized into six different areas and a detailed review of these is presented in the following sections. 


\section{Valuation of Stocks and Functioning of Indian Stock Market}

The work in this area can be classified into three broad strands: a) those dealing with functioning of securities markets and financial institutions operating in these markets, b) those pertaining to the investment decision making process of individuals, and c) empirical work on Indian stock markets.

One of the early works on functioning of stock markets and financial institutions was by Simha, Hemalata and Balakrishnan (1979). Bhole (1982) wrote a comprehensive book on the growth and changes in the structure of Indian capital markets and financial institutions. The book was subsequently updated and revised in 1992. Several books have been written on security analysis and investment in Indian stock markets: Bhalla (1983); Jain (1983), Sahni (1986), Singh (1986); Chandra (1990a), Raghunathan (1991), Avadhani (1992); Yasaswy (1985, 91, 92a, 92b) and Barua et al (1992). These books are primarily written for initiating lay investors to techniques for security analysis and management of investment portfolios. Basu \& Dalal (1993), Barua \& Varma (1993a) and Ramachandran (1993) have critically examined various facets of the great securities scam of 1992.

Several studies, for example, Sahni (1985), Kothari (1986), Raju (1988), Lal (1990), Chandra (1990b), Francis (1991a), Ramesh Gupta (1991a,c, 1992a), Raghunathan (1991), Varma (1992a), L.C. Gupta (1992) and Sinha (1993) comment upon the Indian capital market in general and trading systems in the stock exchanges in particular and suggest that the systems therein are rather antiquated and inefficient, and suffer from major weaknesses and malpractices. According to most of these studies, significant reforms are required if the stock exchanges are to be geared up to the envisaged growth in the Indian capital market.

The investment decision making process of individuals has been explored through experiments by Barua and Srinivasan $(1986,1987 \mathrm{a}, 1991)$. They conclude that the risk perception of individuals are significantly influenced by the skewness of the return distribution. This implies that while taking investment decisions, investors are concerned about the possibility of maximum losses in addition to the variability of returns. Thus the mean variance framework does not fully explain the investment decision making process of individuals. Gupta (1991b) argues that designing a portfolio for a client is much more than merely picking up securities for investment. The portfolio manager needs to understand the psyche of his client while designing his portfolio. According to Gupta, investors in India regard equity debentures and company deposits as being in more or less the same risk category, and consider mutual funds, including all equity funds, almost as safe as bank deposits. Chandra 
(1989) discusses the mistakes made by individual investors in designing their portfolios and suggests suitable remedial measures.

In his recent book, L.C. Gupta (1992) concludes that, a) Indian stock market is highly speculative; b) Indian investors are dissatisfied with the service provided to them by the brokers; c) margins levied by the stock exchanges are inadequate and d) liquidity in a large number of stocks in the Indian markets is very low. While evidently a painstaking work, the conclusions except ' $c$ ' above seem to be built on wrong or questionable arguments.

Mayya (1977), Barua and Raghunathan (1982) and Prabhakar (1989) examined empirically the hedge provided by stocks and bullion against inflation. These studies found that while gold provided complete hedge against inflation, silver and stock were only partial hedges against inflation. Rao and Bhole (1990) arrive at a similar conclusion about stocks. However, as these works pertain to the period prior to the booming 1980's and 1990's, the conclusion that stocks are not an inflation hedge is of doubtful validity today. A similar study covering the more recent years would be very useful as one may reach a very different conclusion. With a booming stock market since the second half of eighties and the stagnation in the international price of gold, such a study may find that stocks and not gold provide complete hedge against inflation.

The issue of inflation hedge has also been researched in the context of stocks. Varma (1991) compares the BSE National Index (Natex) which comprises 100 scrips with the Sensitive Index (Sensex) comprising 30 scrips and concludes that the Natex is a sluggish index which responds too slowly to market conditions. Changes which are reflected in the Sensex on any day are completely reflected in the Natex only by the next day. He finds that Sensex is more volatile than Natex. He concludes for this and other reasons that those who follow the Natex because of its greater comprehensiveness and theoretical appeal may be mistaken. The Sensex needs to be taken more seriously as a sound market index.

The observed deficiencies of the Natex raise several disturbing questions for finance theorists and researchers. Is the market for the less well traded securities in the market inefficient? Do the scrips constituting the Sensex lead the other scrips? If so, can this relationship be used to make extra normal returns? Does the Bombay market lead other exchanges which are also represented in the Natex? These issues call for further research, especially since such questions have been raised by many, including the SEBI of late. 
On whether SEBI has been successful in improving the functioning of Indian stock markets, the conclusions are mixed. Francis (1991b), Barua (1993)). Dhillon (1993), in his doctoral dissertation studies the regulatory policies of Bombay Stock Exchange (BSE) over a four year period (July 1986 June 1990). His findings show that regulatory authorities decide changes in their margin policy on the basis of market activity. He finds that the margins are prompted by changes in settlement returns, price volatility, trading volume and open positions. Granger causality results show that there is limited causality in the reverse direction: margin changes do not affect returns, and have only a limited impact on price volatility, trading volume and open positions. Event study methodology applied to daily margins show similar results, except that daily margin on sellers do not appear to be affected by market variables. Further, there is also evidence of under margining leading to excessively levered positions, thereby increasing the insolvency risk. The above results reveal that regulations through these instrument have had only a marginal impact on the dual objectives of controlling market activity and insolvency risk.

Pandya (1992) observes that as a regulatory and development body, SEBI's efforts in the direction of investor protection are varied and unlimited. The measures brought in by SEBI broadly cover measures for allocative efficiency in the primary market with fair degree of transparency, reforms in the secondary market for visible and mutual funds, regulation of various market intermediaries and above all for the protection of the investing public.

Venkateshwar (1991) explores the relationships of the Indian stock markets as reflected by the Bombay Stock Exchange Index, vis-a-vis other prominent international stock markets. 23 international Stock indices are used over the period 1983-87. He concludes that there is practically no meaningful relationship between the BSE index and other international stock market indices, though the British and South Korean indices are inversely related to BSE.

Raghunathan and Varma (1992a) point out that any comparison of the Indian stock market with those elsewhere must be carried out on a common currency base. They find that in dollar terms, the SENSEX return over the $1960-92$ period is only about $0.5 \%$, while during the same period the returns in the U.S. (based on the S \& P Index) and the Japanese (based on the NIKEI index) are $6.1 \%$ and $11.4 \%$ per year respectively. Over the twelve year period 1980-92, the dollar returns for SENSEX, S $\& \mathrm{P}$ and NIKEI indices turn out to be $6.5 \%, 10.65 \%$ and $13.6 \%$ respectively. For a shorter span of seven years, namely 1985-92, the returns for the three indices turn out to be quite comparable at $15 \%$, $13 \%$ and $14 \%$ respectively. 
Very little theoretical work has been done in the field of equity valuation in the Indian context. Even when some work has been done, it is a mere extension of the well known works of Modigliani and Miller. For example, Raghunathan and Varma (1991) provide a reasonably comprehensive valuation model which captures most of the complexities and subtleties of real world. The model is capable of supporting both the Gordon and MM type assumptions about the investment policy of the firm. It allows for personal taxes with differential tax rates for dividends, interest, and capital gains. The model also takes into account flotation costs on debt and equity. Further, unlike other models which define capital gains as increase in the book value which in turn equals retained earnings, this model interprets capital gains as increase in the market value of the share. Finally, the model is modified to take into account the fact that inflation erodes the real value of the firm's assets, particularly the net monetary working capital.

Some of the other theoretical works on valuation pertain to the Indian debentures and bonds with unspecified conversion terms. These are discussed under the section on the valuation of bonds and debentures.

There are several empirical works pertaining to the pricing of equities. Pandey (1981) examines the impact of leverage on equity prices and concludes that Modigliani-Miller hypothesis is not supported. However, the risk proxy used in the paper, namely, coefficient of variation of net operating income, is highly questionable. Zahir and Yakesh (1982) find the dividend per share to be the most important variable affecting the share price, followed by dividend yield, book value per share, dividend coverage and the return on investment, in that order. Balakrishnan (1984) also finds that the current dividend and book value per share are more important determinants of market price as compared to earnings per share and dividend coverage.

Barua and Raghunathan (1990a) use the Gordon's dividend growth model to show that the prevailing $\mathrm{P} / \mathrm{E}$ multiples in the Indian capital market around the second and third quarter of 1990 are on the higher side. Sinha (1992) argues that the high P/E ratio observed in March 1992 is partly attributable to abnormally low earnings during 1991-92 and partly to the high P/E ratios of MNCs. Even after adjusting for these two factors, he finds the $\mathrm{P} / \mathrm{E}$ ratio to be relatively high. 


\section{Valuation of Bonds, Convertible Debentures and Market for Debt}

In developed economies, bond markets tend to be bigger in size than the equity market. In India however, corporate bond market is quite small compared to the size of the equity market. One of the main reasons for this is that a large part of corporate debt, being loan from financial intermediaries, is not securitised. The picture however is undergoing a sea change in the last few years. An increasingly larger number of companies are entering the capital market to raise funds directly form the market through issue of convertible and non-convertible debentures. The deregulations on interest rates in the new liberalized environment is also resulting in innovative instruments being used by companies to raise resources from the capital markets.

The book written by Sen and Chandrashekar (1986) was a compendium of rules, regulations and procedures for issue of debentures. The articles by Atmaramani (1984) and Premchander (1989) deal with changes needed in the guidelines governing issue of debentures to ensure that the instrument becomes popular with investors.

The work done by Kapadia (1981), Kapoor (1981), Sinha (1983), Chaudhury (1985) analyze the usefulness of convertible debentures (CDs) as an instrument for raising resources from the capital markets. After stating that CDs have provided attractive returns to investors, Chaudhury identifies lack of liquidity and Sinha identifies capital gains tax as two possible dampeners to CDs finding favour with investors.

Barua and Srinivasan (1987b) and Barua and Raghunathan (1990b) examine the terms on which convertible debentures are issued to investors. The former argue that the extremely low conversion price (in relation to the prevailing share price) was unfair to the existing shareholders of the company as it implied a forced transfer of wealth to new shareholders. Barua and Raghunathan focus attention on the compulsory conversion of CDs into shares and argue that conversion ought to be optional so that CDs would acquire the features of a call option. Both these lacunae in the terms on which CDs can be issued have now been removed under the guidelines prevailing today.

Barua, Madhavan and Varma (1991) examine the case of CDs with unspecified conversion terms. Such securities, which were unique to the Indian capital markets, had become quite popular in the last few years of the eighties. Analyzing a large issue of CDs with unspecified terms they concluded that while under normal circumstances one would expect the share prices to govern the prices of CDs (since the latter is supposed to be the derived security), if conversion terms are not specified, changes in the expectations about the conversion terms could start affecting the share prices through the 
dilution effect. Analyzing the issue further Barua and Varma (1991a) develop a theoretical model for valuation of CDs with unspecified terms and show that an investor in these securities cannot protect himself from both sources of risk: changes in the value of the firm and changes in the conversion ratio. They finally argue that CDs should be allowed to be issued only on clearly specified terms. The new regulations require the issuers to specify the conversion terms clearly thereby removing a major lacuna which existed earlier.

Raghunathan and Varma (1992b) examine the quality of credit rating being done by CRISIL. They find that CRISIL's AAA ratings are not only not consistent with international rating norms but they are also internally inconsistent. They also find that the qualitative factors listed cannot satisfactorily explain the inconsistencies found in the ratings. Extending the work done earlier, Raghunathan and Varma (1993) find that a naive model of simply taking an average value of all the variables considered by CRISIL for rating provides a far more consistent rating of companies than the model that CRISIL may have used to actually rate the companies. Based on the above analysis, they argue that there is a need to allow entry of private rating agencies to ensure that the exercise is done more meaningfully. Sankar (1992) also points out several flaws in CRISIL's credit ratings.

An off-beat work in this area is done by Varma (1989) on valuation of special bearer bonds. A valuation model is developed which extends the CAPM to take into account the risk of tax raids on holders of these bonds for unearthing black money. The analysis shows that the pricing of all other assets relative to each other would be unaffected by the presence of black money in the economy.

While a variety of work has been done on convertible and non-convertible debentures, in view of the sea change in the regulatory regime, a fair amount of past work is only of historical significance, providing little guide to what kind of situation would prevail in the future. This has become a very critical area of research in Indian capital markets.

Barua et al (1994) undertake a comprehensive assessment of the private corporate debt market, the public sector bond market, the Government securities market, the housing finance and other debt markets in India. The paper is mainly a diagnostic study of the state of the Indian debt market, recommending necessary measures for the development of the secondary market for debt. It highlights the need to integrate the regulated debt market with the free debt market, the necessity for market making for financing and hedging options and interest rate derivatives, and tax reforms. 


\section{New Issue Market and Merchant Banking}

There is a paucity of research done in the new issue market in India. What is worse is that much of whatever little work has been done, dates back to the late 1970's and early 1980's prior to the qualitative transformation that took place in the Indian equity markets in the 1980's. Moreover, the advent of free pricing in 1992 has changed the dynamics of the new issue market almost beyond recognition. All this means that the bulk of the work being reviewed here is of doubtful relevance in today's context.

It also means that the new issue market is one of the areas where substantial research needs to be done in the years ahead. One redeeming feature for researchers in this field is the vastly improved quality and coverage of commercially available databases. Data which earlier had to be painstakingly pieced together from hundreds of prospectuses is now available in machine readable form. This would, we hope, spur an increasing amount of research on this important area.

From an academic point of view, the most significant work in the field of new issues in India is that of Gujarathi (1981) who examined the question of the risk adjusted return in the new issues market. As in all studies of new issues, the difficulty of estimating the risk (beta) of newly issued securities forces Gujarathi to use a complicated methodology for arriving at the risk adjusted return. His conclusion is that investors in the new issues market in 1970's earned an extra normal return of nearly $2 \frac{1}{2} \%$ per month!

Khan $(1977,1978)$ studied the role of new issues in financing the private corporate sector during the 1960 's and early 1970's and concluded that new issues were declining in importance. He also showed that with underwriting becoming almost universal, institutions like the LIC and the UTI were becoming major players.

Jain (1979) shed more light on this question with an analysis of UTI's role in the new issue market. He argued that UTI looked at underwriting as a method of acquiring securities at low cost rather than an arrangement for guaranteeing the success of new issues. In the context of the rapidly changing structure of the merchant banking industry in India today, a deeper analysis of the motivations and strengths of different players would be highly useful.

Chandra (1989a) and Varma and Venkiteswaran (1990) critically examine the CCI guidelines for valuation of shares and point out that the CCI's methodology is fundamentally flawed. With the 
abolition of the office of the CCI, the issue of pricing using the CCI methodology has however become redundant.

Anshuman and Chandra (1991) examine the government policy of favouring the small shareholders in terms of allotment of shares. They argue that such a policy suffers from several lacunae such as higher issue and servicing costs and lesser vigilance about the functioning of companies because of inadequate knowledge. They suggest that there is a need to eliminate this bias as that would lead to a better functioning capital market and would strengthen investor protection. With proportional allocation being advocated by SEBI, a shift in the policy is already evident. However, there appears to be some re-thinking on proportional allocation after the recent experiences which clearly demonstrate that such a policy could result in highly skewed ownership patterns.

Much of the work in the field of merchant banking is descriptive in nature. Dhankar's book (1986) deals with procedural aspects of merchant banking. Verma's book (1990), on the other hand, deals with organization and management of merchant banking function.

Bhatt (1980) makes certain general observations on the merchant banking function. According to him, the most important merchant banking functions are promotion, financing and syndication of loans for projects in the country including for foreign collaborations; investment advisory services, investment management and advice on joint ventures abroad. Such merchant banking institutions can also assist non resident Indians in investing their funds in shares of new companies in India, bonds, securities etc.

Agrawal (1980) stresses the need to redefine the underwriting function. He underscores the need for distinguishing underwriting from investing. In his opinion such a distinction does not exist in India.

Saha (1988) argues that the strategy of merchant bankers should not be to develop an instrument for raising capital from the market, but to develop a process that makes creation and delivery of the instruments possible in accordance with the pace and requirements of the issuers.

Trikha (1989) highlights the lack of professionalism of the merchant bankers in India as regards their attitude towards the investing public. The concern has become even more relevant today.

None of the papers concerning merchant banking are rigorous in terms of analytical investigation of the merchant banking industry. With the opening up of the Indian economy, merchant banking is one 
activity which would become crucial for sustained economic development. This is one area therefore where concerted research is required.

\section{Market Efficiency}

Three types of informational efficiency (weak, semi-strong and strong) have been well identified by researchers in the field of capital markets throughout the world.

Weak efficiency states that current prices fully reflect all the information contained in the history of past prices and denies the utility of charting and technical analysis. This issue has been researched in India over a long period and the overwhelming preponderance of evidence, for example, Barua (1980, 1987); Sharma (1983); Ramachandran (1985); Sharma and Kennedy (1977); Gupta (1985) is in favour of weak form efficiency. There have been only a few studies (Kulkarni (1978) and Chaudhury $(1991 \mathrm{a}, \mathrm{b}, \mathrm{c}))$ which did not support the weak efficiency hypothesis.

In the light of the above evidence, the results of Bhat and Pandey (1987) appear paradoxical. On the basis of a questionnaire survey, they conclude that the users and preparers of accounting information in India do not believe that the market is efficient in any of its three forms.

Bhat (1988a) studies the relationship between the regional market indices in the Indian stock market over the period 1971-85 using monthly data. He finds that the regional price indicators respond immediately to the all India index, but cautions that his study is not adequate to conclude the existence of an integrated national market.

Semi strong form of efficiency deals with the speed with which publicly available information is assimilated by the market and incorporated in market prices. The evidence on this issue is mixed.

Subramaniam (1989) found that in the case of political events, the market appeared to respond more efficiently to events whose impact on share values was characterized by low complexity and high clarity. The market seemed to have difficulty with ambiguous and complex events. Ramachandran (1985) and Srinivasan (1988) found that the market was by and large efficient in responding to the information content of bonus issues and rights issues respectively.

A closely related question is the extent to which share prices reflect (publicly known) fundamentals. Dixit (1986) shows that dividend is the most important determinant of share prices. This is consistent with standard theories of fundamental value. However, Barua and Raghunathan (1990a), Sundaram 
(1991) and Obaidullah (1991), Sinha (1992) cast doubts on whether the observed price earnings ratios are consistent with fundamental factors like dividend growth and payout ratios.

Another related question is whether the pricing in Indian markets is consistent with the risk return parity postulated by the Capital Asset Pricing Model (CAPM). While Varma (1988) and Yalawar (1988) provide evidence in favour of the CAPM, Srinivasan (1988) argues that the CAPM relationship holds only in the long run. The validity of the CAPM is important as many tests of the efficient market hypothesis implicitly assume the validity of the CAPM. More detailed tests of the CAPM and also of the competing Arbitrage Pricing Theory are important areas for future research.

Barua and Raghunathan (1986) provide evidence of the systematic mispricing of convertible securities in violation of the risk return parity and argue that this represents an arbitrage opportunity. Though this paper provoked a heated debate on whether the arbitrage opportunity was really risk free, the mispricing of convertible securities remains an unexplained anomaly.

Regarding the behaviour of interest rates and fixed income securities, there is hardly any research yet. Interest rates have been progressively freed since 1991 but the transition to a total free market regime is likely to be complete only by the mid 1990's. The study by Nachane (1988) of the few interest rates that have historically been subject to some extent to market forces assumes significance in this context. Nachane found that the market for lendable funds as reflected in the call market rate, bazaar bill rate and the SBI Hundi rate is inefficient. The Fisherine hypothesis that interest rates reflect anticipated inflation is also rejected.

The third form of market efficiency (strong from) asserts that even inside information which is not publicly available is reflected in market prices very rapidly. This hypothesis is usually tested by evaluating the performance of mutual funds whose managers can be expected to have some degree of inside information. The research in this field is discussed in a separate section of this review. 


\section{Dividends, Bonus \& Rights Issues and Rates of Return}

In a unique work of its kind, L.C. Gupta $(1980,1981)$ examines the characteristics of the rates of return on equities in the Indian capital market for a fairly large sample of 276 companies over a sixteen year period from 1961-76. He concludes that the rates of return provided by equities are unsatisfactory because: a) about $20 \%$ of returns for various holding periods are negative, b) the returns provide only a partial hedge against inflation, c) the fluctuations in returns even within a year are large enough to conclude that timing of transactions decisions have significant bearing on realized returns, d) the risk is considerable even when investment is made in a portfolio of securities and for long periods of time. While the study is an important milestone in research in Indian capital market, given the equity cult that started after forced dilution by MNCs because of FERA in the late seventies and the rise in the equity returns since the second half of eighties, the conclusions of the study are unlikely to be valid now for the Indian market. A comprehensive study of that kind for the more recent period is called for.

Gujarathi and Srinivasan (1980) discuss the issue of discount coupons being distributed, particularly by textile mills, for purchasing the products of the companies. They argue that such coupons are akin to payment of (disguised) dividends which would not be taxed. Srivastava (1984) does a cross section study of 327 companies for the year 1982-83 to conclude that high dividend rates are associated with higher market prices of securities. He therefore states that the famous Modigliani-Miller Model that dividends have no impact on share prices is not applicable in the Indian context. The analysis suffers from several limitations, the most obvious being the fact that had the researcher examined the relationship between earnings and dividends, he would have in all likelihood found that the higher dividend paying companies are also the ones with higher earnings. Unless the hypothesis of spurious relationship between prices and dividends because of both being related to earnings is examined and rejected, the conclusion of the study would be suspect. Dholakia and Bhat (1986) attempt to decompose the riskiness of shares into risk in dividend and risk in capital gains. Their study suggests that there is a negative relationship between dividends and capital gains.

Research on bonus issues has dealt with two main sets of issues: (a) the bonus policy and the post bonus dividend policy of companies, and (b) the efficiency with which the stock market assimilates information about bonus issues.

Gupta (1991) argues on the basis of a study of 25 large companies over a ten year period that bonus policy of companies is characterized by low bonus, irregular intervals and inconsistent policy. This is 
an area which needs further study as Gupta's sample is too small to arrive at any definitive conclusions. In fact, we know too little about how companies decide on bonus issues; certainly, we know less about bonus policy than about dividend policy.

There is considerably more work on the post bonus dividend performance. Academics have long argued that the real significance of bonus issues is that they signal management's perception of higher profits and dividends in future. Early studies by L.C. Gupta (1978) indicated that a third of the companies did not raise the dividend quantum and that significant number even reduced the dividend. Gupta, in fact, cautioned investors not to be carried away by the speculative fervour surrounding the bonus issue. Later studies, however, present a very different picture. Sarma (1993) shows that during the period 1977-1988, an overwhelming majority of the bonus issues were accompanied by increased dividend quantum in the bonus year itself. The range of increase was also large and in many cases, the old dividend percentage was maintained on the enlarged equity base. Sarma's study also indicated that the bonus per se has no effect on the share value and supported the view that bonus merely signals higher future profits and dividends.

There is considerable evidence to suggest that the market assimilates information regarding bonus issues rapidly and efficiently. In an efficient market, the share starts rising in anticipation of the bonus announcement and completes its rise immediately after the announcement. Ramachandran (1985) and Ramachandran (1992) both provide evidence that this is so. Obaidullah (1992) also concludes that there is no evidence to suggest that learning lags exist or that the assimilation of information is slow.

Rights issues made below market prices are similar to bonus issues in some respects. In fact, a rights issue at a discount from the market price can be decomposed conceptually into a bonus issue and a rights issue at market prices. Hingorani (1978) analyses the value of rights shares and illustrates the advantage derived by the investor.

Srinivasan (1993) studied the efficiency of the market in assimilating the information content of rights issues and concluded that the market was by and large efficient.

One unresolved issue in the field of rights and bonus issues is the price correction on the ex-bonus and ex-rights days. While these corrections are not equal to the theoretical corrections, the issue is complicated by tax arbitrage considerations and by liquidity effects. This unresolved anomaly deserves fuller study. 
Barua, Madhavan and Raghunathan (1987) show that the beta coefficient of a security, when returns are measured using discrete time frame, vary with the length of the period used for computation for returns. The systematic risk of a security if such a method is used would therefore depend on the assumption about the holding period of investors.

Rao and Bhole (1990) have examined the real rates of return on equities in the Indian market for the period 1953-87. They conclude that equities provide only a partial hedge against inflation. While the long term real rates of return are positive, during periods of extraordinarily high inflation, the real rates of return are negative. The study would have been more useful had the returns provided by bullion also analyzed for the same period. It would also have been useful to break up the long period into sub-periods to determine whether the behaviour of returns was different for different sub-periods and whether reasons could be ascribed for any observed differences. As observed earlier in the paper, as the Indian stock market has been booming in recent years, the conclusions for a more recent period could be quite different from the conclusions reached in the study.

Ignatius (1992) has done an interesting study comparing the returns in the BSE with those in the NYSE. He finds a mildly significant weekend effect in the returns on equities in India as well as seasonality in return, with the month of December providing significantly higher monthly return. Overall, the return patterns in the BSE and the NYSE appear to be similar. A more rigorous study of this kind involving other markets would be very useful at the present juncture when the Indian market has been thrown open to investment by foreigners, since such a study can assess whether there could be gains from portfolio diversification through investment in the Indian capital markets. 


\section{Performance and Regulation of Mutual Funds}

The first close ended mutual fund was floated in the Indian capital market just over seven years ago in September 1986. Today, there are more than 130 schemes in the market and the last few months have witnessed the entry of private sector in this fledgling industry. Given the brief history, it is hardly surprising that there is paucity of research on Mutual Funds. One of the earliest empirical research in the area was done by Barua and Varma (1990). They examined the performance of Mastershares, the first close end Mutual Fund, both in terms of NAV and market prices. They found that though in terms of NAV the risk adjusted performance of Mastershares was superior to the market, in terms of market prices the performance was inferior to the market. The initial work was refined in the subsequent paper by the same authors (1991b) which concluded that the performance of Mastershares from the point of view of a small investor (whose equity investment would primarily be in terms of holding of Mastershares) was poor while from the point of view of a large investor (for whom Mastershares would be one of the securities in the portfolio) the performance was excellent. The research raised an interesting issue about the purpose of mutual funds: if they are meant primarily for small investors, then Mastershares have failed to serve the purpose. In another paper Barua and Varma (1993b) have examined the relationship between the NAV and the market price on Mastershares. They conclude that market prices are far more volatile than what can be justified by volatility of NAVs. The prices also show a mean reverting behaviour, thus perhaps providing an opportunity for discovering a trading rule to make abnormal profits in the market. Such a rule would basically imply buying Mastershares whenever the discount from NAV was quite high and selling Mastershares whenever the discount was low.

The earliest work on evolving a regulatory framework for the fledgling industry was done by Barua, Varma and Venkiteswaran (1991). Drawing heavily on the regulatory framework for operation of mutual funds in the U.S.A. (Investment Company Act of 1940), the authors proposed detailed guidelines that could be adopted for mutual funds operating in the Indian capital markets.

The other papers on mutual funds are descriptive in nature and conjecture about the future scenario in the Indian capital market. Vidhyashankar (1990) concludes that mutual funds would emerge as the predominant instrument for savings by the household sector by the turn of this century. Mahendra (1991) reaches a similar conclusion when he states that mutual funds would dominate the Indian capital markets. Bal and Mishra (1990) conjecture that mutual funds would play an important role in developing the Indian capital markets. 


\section{In conclusion}

In a broad ranging review of this kind, no amount of care usually suffices to save the authors from being found guilty of omissions - even glaring omissions. We tried to exercise as much care as possible to ensure that we did not miss any research done after 1977 on the Indian capital markets. Some omissions are bound to have occurred because of reasons beyond our control. Though we put in fair amount of effort in identifying all relevant institutions, it is possible that we perhaps did not write to all institutions engaged in research on the Indian capital markets. Since only 53 institutions responded out of 118 institutions we wrote to, it is quite possible that some unpublished research works have not been included in the works reviewed. We can only regret such omissions. We would be grateful to the readers of this paper if they bring to our notice such omissions so that we could make the coverage more comprehensive in the next update of the paper.

On the basis of the exercise undertaken by us, we consider it obligatory to make some brief comments on the state of capital market research in India.

Certain areas such as arbitrage pricing theory, option pricing theory, agency theory, and signalling theory are virtually unresearched in the Indian context. Besides, very little theoretical work has been done by researchers in India.

A major malady with which most of the works suffer from is the lack of referencing. Unlike in the more developed research environments where any academic work can be traced back to the origin by following the references backward in time, each piece of research in India is more or less a stand alone piece. It is not unusual to come across papers without any references whatsoever! Where references exist, they are often incomplete, besides being only cosmetic (not quite relevant to the work), so that it may be virtually impossible to find a common thread across different works. The situation is hardly helped by the fact that journals in India are seldom refereed in the true sense of the word.

Considering the size, vintage and the extent of development of the Indian capital market, the total volume of research on it appears to be woefully modest. For example, the total number of research works (each book, dissertation or paper counted as a work) over the 15 year span (1977-92) for 118 potential research institutions is only 180 - about 0.1 unit of work per institution per year! A large number of works are merely descriptive or prescriptive without rigorous analysis. If one were to

apply a strict definition of research, one may have to exclude about half of the works cited in this 
paper. Further, not only is the average research output very low but the distribution of work done by the institutions and individuals is highly skewed. To some extent, this skewness might have been exacerbated by the fact that the authors of this paper have had more complete access to the works of their own institution as compared to other institutions. The main reason as to why Indian capital market is grossly under-researched is perhaps because of lack of availability of databases and computing resources. Both these limitations are being removed and we are optimistic that one is likely to witness an explosion of work in the near future. The current interest of foreign investors in the Indian capital market, if it is sustained, would also help give a fillip to research. 


\section{Bibliography}

I. Agrawal G D (1992), "Mutual Funds and Investors' Interest", Chartered Secretary, Vol. 22, No. 1 (Jan), p. 23.

II. Agrawal N C (1980), "Underwriting Operations in India: Reexamination Needed", Chartered Accountant, Vol. 28, No. 11 (May), p. 1001-1005.

III. Agarwal P C (1992), "Suggestions on Scripless Trading", Chartered Secretary, Vol. 22, No. 10 (Oct), p. 888.

IV. Anshuman A S \& Prakash Chandra R (1991), "Small Equity Shareholdings : The Repurcussions", Chartered Secretary, Vol 21, No. 7 (Jul), p. 562.

V. Atmaramani K A (1984), "Issue of Non-Convertible Debentures by public limited companies", Chartered Secretary, Vol. 14, No. 7 (Jul), p. 463-468.

VI. Avadhani V A (1992), Investment \& Securities Markets in India: Investment Management, Himalaya Publishing, Bombay. p 426.

VII. Bal R K, Mishra B B (1990), "Role of Mutual Funds in Developing Indian Capital Market", Indian Journal of Commerce, Vol. XLIII, p. 165.

VIII. Balasubramaniam C S (1980), "Indexes of Ordinary Share Prices - An Evaluation", Artha Vijnana, Vol. 22 No. 4 (Dec) p. 552-564.

IX. Balasubramaniam N (1993), Corporate Financial Policies and Shareholders Returns : The Indian Experience, Himalaya Publishing, Bombay, p. 266.

X. Balkrishnan (1984), "Determinants of Equity Prices in India", Management Accountant, Vol. 19, No. 12 (Dec), p. 728-730.

XI. Barua S K (1980), "Valuation of Securities and Influence of Value on Financial Decision of a Firm", Doctoral Dissertation, Indian Institute of Management, Ahmedabad.

XII. Barua S K (1981), "Short-run Price Behaviour of Securities: Some Evidence of Indian Capital", Vikalpa (Apr-Jun) Vol. 6, No. 2, p. 93-100.

XIII. Barua S K \& Raghunathan V (1982), "Inflation Hedge in India - Stocks or Bullion", Working Paper No. 429, (July- Sept), Indian Institute of Management, Ahmedabad.

XIV. Barua S K \& Srinivasan G (1982), "Experiment on Individual Investment Decision Making Process", Working Paper No. 423, (Apr-June), Indian Institute of Management, Ahmedabad.

XV. Barua S K \& Raghunathan V (1986), "Inefficiency of the Indian Capital Market", Vikalpa, Vol. 11, No. 3,(Jul-Sept), p. 225-230.

XVI. Barua S K (1987), "Some Observations on the Report of the High Powered Committee on Stock Exchange Reforms", Annual Issue of ICFAI, December 1987. 
XVII. Barua S K, Madhavan T \& Raghunathan V (1987), "Implications of Changes in the Holding, period and Other, parameters on Systematic Risk and Performance of a Security", Working Paper No. 664, (Jan-Mar), Indian Institute of Management, Ahmedabad.

XVIII. Barua S K \& Raghunathan V (1987), "Inefficiency and Speculation in the Indian Capital Market", Vikalpa, Vol. 12, No. 3,(Jul-Sept), p. 53-58.

XIX. Barua S K \& Srinivasan G (1987a), "Investigation of Decision Criteria for Investment in Risky Assets", OMEGA: International Journal of Management Science, Vol. 15, No. 3, p. 247-253.

XX. Barua S K \& Srinivasan G (1987b), "Setting the Terms for Convertible Debenture Issues : Should the Spirit of Company Law be Violated?", Vikalpa, Vol. 12, No. 1, (Jan-Mar), p. 5761.

XXI. Barua S K \& Raghunathan V (1988), "Testing Stock Market Efficiency Using Risk-Return Parity Rule : A Reply (Notes \& Comments)", Vikalpa, Vol. 13, (Jul-Sept), p. 82-83.

XXII. Barua S K \& Srinivasan G (1988), "The Decision Process of Individuals under Conditions of Risk : An Experimental Study, International Journal of Management, Vol. 5, No. 3, (Sept), p. 251-258.

XXIII. Barua S K \& Raghunathan V (1990a), "Soaring Stock Prices: Defying Fundamentals", Economic \& Political Weekly, Vol. 25, No. 46, Nov 17, p. 2559-2561.

XXIV. Barua S K \& Raghunathan V (1990b), "Convertible Securities \& Implied Options", Vikalpa, Vol. 15, No. 4 (Oct-Dec), p. 23-28.

XXV. Barua S K \& Varma J R (1990), "Mastershares : Enigmatic Performance", Working Paper No. 906, (Oct-Dec), Indian Institute of Management, Ahmedabad.

XXVI. Barua S K \& Varma J R (1991b), "Mastershares: A Bonanza for Large Investors", Vikalpa, Vol. 16,No. 1 (Jan-Mar), p. 29-34.

XXVII. Barua S K \& Varma J R (1991a), "Indian Convertible Bonds with Unspecified Terms: A Valuation Model", Working Paper No. 991, (Jul-Sep), Indian Institute of Management, Ahmedabad.

XXVIII.Barua S K \& Varma J R (1991), "Mastershares: Market Prices Divorced from Fundamentals", Working Paper No. 953, (Jul-Sep), Indian Institute of Management, Ahmedabad.

XXIX. Barua S K, Varma J R, Venkiteswaran N (1991), "A Regulatory Framework for Mutual Funds", Economic \& Political Weekly, Review of Management \& Industry, Vol. 26, No. 21, May 25, p. 55-59.

XXX. Barua S K, Madhavan T \& Varma J R (1991) "Indian Convertible Bonds with Unspecified Terms: An Empirical Study", Working Paper No. 990, (Oct-Dec), Indian Institute of Management, Ahmedabad. 
XXXI. Barua S K \& Srinivasan G (1991), "Experiment on Individual Investment Decision Making Process", Sankhya, Vol. 53, Series B, p. 74-88.

XXXII. Barua S K, Raghunathan V \& Varma J R (1992), Portfolio Management, Tata McGrawHill, New Delhi, p. 256.

XXXIII.Barua S K \& Varma J R (1992), "Gorbachev Betas : The Russian Coup and The Market Blues", Working Paper No. 1054, (Jul-Sept), Indian Institute of Management, Ahmedabad.

XXXIV.Barua S K \& Varma J R (1993a), The Great Indian Scam: Story of the Missing Rs 4000 crore, Vision Books, Delhi, p. 160.

XXXV.Barua S K \& Varma J R (1993), "Securities Scam: Genesis, Mechanics and Impact", Vikalpa, Vol. 18, No. 1 (Jan-Mar), p. 3-12.

XXXVI.Barua S K \& Varma J R (1993), "RBI Autonomy and the Indian Financial Sector", Vikalpa, Vol. 18, No. 4 (Oct-Dec), p. 15-19.

XXXVII.Barua S K (1993), "SEBI's Regulatory, priorities: Need for Change", Unpublished, paper for the Ministry of Finance, Indian Institute of Management, Ahmedabad.

XXXVIII.Barua S K \& Varma J R (1993b), "Speculative Dynamics: The Case of Mastershares", Advances in Financial Planning and Forecasting, Vol. 5, Jai Press, Greenwitch, CT, USA.

XXXIX.Barua S K, Raghunathan V, Venkiteswaran N \& Varma J R (1994), "Analysis of the Indian Securities Industry: Market for Debt", Working Paper No. 1164, Indian Institute of Management, Ahmedabad.

XL. Basu Debasish \& Dalal Sucheta (1993), Scam: Who Won, Who Lost, Who Got Away, UBS Publishers \& Distributors, New Delhi, p. 294.

XLI. Bhalla U K (1983), Investment Management : Security Analysis and Portfolio Management, S. Chand, New Delhi, p. 391.

XLII. Bhatt M C (1980), "Merchant Banking in India : Its Contribution to National Development", Chartered Secretary, Vol. 10,No. 10, (Oct), p. 922.

XLIII. Bhatt Ramesh K (1981), "Pitfalls of the Price-Earnings Ratio", Chartered Accountant, Vol. 30, (July), p 19.

XLIV. Bhat Ramesh \& Pandey I M (1987), "Efficient Market Hypothesis : Understanding and Acceptance in India", Working Paper No. 691, (Jul-Sept), Indian Institute of Management, Ahmedabad.

XLV. Bhat Ramesh (1988a), "An Empirical Study of the Intertemporal Relations Among the Regional Share Price Indicators", Working Paper No. 748, (Apr-Jun), Indian Institute of Management, Ahmedabad. 
XLVI. Bhat Ramesh (1988), "Market-Wide Commonalities in Corporate Earnings and Significance Tests of Accounting Betas", Working Paper No. 750, (Apr-Jun), Indian Institute of Management, Ahmedabad.

XLVII. Bhattacharya C D (1981), "A Study on the Wealth Ratios of Indian Companies", Working Paper No. 354, Indian Institute of Management, Ahmedabad.

XLVIII.Bhattacharya C D (1981), "A Study on Share Valuations of Indian Companies", Working Paper No. 355, Indian Institute of Management, Ahmedabad.

XLIX. Bhattacharya C D (1981), "Variance Analysis to chances in return of Investment", Working Paper No. 365, (Apr-Jun), Indian Institute of Management, Ahmedabad.

L. Bhole L M (1974), Investment, Interest \& Monetary Policy in India, Bombay University, Bombay.

LI. Bhole L M (1980), "Retained Earnings, Dividends and Share Prices of Indian Joint Stock Companies", Economic \& Political Weekly, Review of Management, (Aug), p. M92-100.

LII. Bhole L M (1982), Financial Markets and Institutions : Growth Structure and Innovations, Tata McGraw Hill, New Delhi, p. 360, I edition.

LIII. Bhole L M (1992), Financial Institutions \& Markets : Structure Growth and Innovations, II Edition, Tata McGraw Hill, Delhi, p. 527.

LIV. Bhole L M (1992), "Proposals for Financial Sector Reforms in India : An Appraisal (Perspectives)", Vikalpa, Vol. 17, No. 3 (Jul-Sep), p. 3-9.

LV. Chandra Prasanna (1977), "Comparison of the Additive and Multiplicative Models of Stock Valuation", Decision, Vol. 4,No. 1 (Jan).

LVI. Chandra Prasanna (1989a), "Pricing of Public Issues", Chartered Financial Analyst, (JulAug), p. 3-7.

LVII. Chandra Prasanna (1989), "Individual Portfolio Management: Mistakes and Remedies", Chartered Financial Analyst, (Sep-Oct), p. 3-5.

LVIII. Chandra Prasanna (1990b), "Indian Capital Market : Pathways of Development", ASCI Journal of Management, Vol. 20, No. 2-3 (Sept-Dec), p. 129-137.

LIX. Chandra Prasanna (1990a), Investment Game: How to Win, Tata McGraw-Hill, New Delhi (1990), p. 230.

LX. Chaudhury S K (1985), "Convertible Debenture : Analysing Yield \& Risk", Management Accountant, Vol. 20, No. 1 (Jan), p. 86-88.

LXI. Chaudhury S K (1991a), "Short Run Behaviour of Industrial Share Price Indices : An Empirical Study of Returns, Volatility and Covariance Structure", Prajanan, Vol. XX, AprJun, No. 2, p. 99-113. 
LXII. Choudhury S K (1991b), "Sesonality in Share Returns: Prelimnary Evidence on Day-of-theWeek Effect", Chartered Accountant, Vol. 40, No. 5 (Nov), p. 407.

LXIII. Chaudhury S K (1991c), "Short-run Share Price Behaviour : New Evidence on Weak form of Market Efficiency", Vikalpa, Vol. 16, No. 4 (Oct-Dec), p. 17-21.

LXIV. Chawla O P (1989), Money And Securities Markets: Emerging Trends, NIBM Pune Conference Papers (Ed).

LXV. Datar P A (1985), "Valuation of Bonus Shares", Chartered Secretary, Vol. XV, No. 3 (March), p. 156.

LXVI. Dilbagh S B (1991), "Indian Stock Market Seasonality : A Note", Indian Economic Journal, Vol 39, No. 2, (Oct-Dec), p. 110-119.

LXVII. Dixit R K (1984), "The Behaviour of Share Price in India", Doctoral Dissertation, Panjab University, Chandigarh.

LXVIII.Dixit R K (1986), Behaviour of Share Prices and Investment in India, Deep \& Deep Publications, New Delhi, p. 328.

LXIX. Dhameja N L (1978), "Control of Companies and their Dividend, practices", Margin, Vol. 10, No. 2, (Jan), p. 30.

LXX. Dhankar J N (1986), A Treatise on Merchant Banking -, project Approval and Financing, Skylark Publications, New Delhi.

LXXI. Dhillon N (1993), "Market Regulations and Stock Market Activity", Doctoral Dissertation, Indian Institute of Management, Ahmedabad.

LXXII. Dholakia R H and Bhatt Ramesh (1986), "Dividend Rate and Variation in Share Prices: An Exploration into their Inter-relationship", Working paper No. 638, Indian Institute of Management, Ahmedabad.

LXXIII.Francis C K (1991a), "Towards a Healthy Capital Market", Yojana, Vol. 35, Mar.1-15, p. 1113.

LXXIV.Francis C K (1991b), "SEBI - The Need of the Hour", SEDME, Vol. 18(3), p. 37-41.

LXXV.Gahan P (1985), "Short term Investment vs Disinvestment under conditions of Certainity - A Decision Making Approach", The Indian Journal of Commerce, Vol. 39, No. 4.

LXXVI.Ganesh R (1988), "Return on Net Worth : A Close Look", Chartered Secretary, Vol. 18 (9), p. 774-778.

LXXVII.Garai S (1989), "Corporate Over-All, performance as Judged by Investors: A Canonical Correlation Analysis of Engineering Industrial Units", Decision, Vol 16 (1), p 53-65.

LXXVIII.Garai S (1989), "Corporate Over-all, performance as Judged by Investors: A Second Look", Decision, Vol. 16, no.4, p 267-280. 
LXXIX.Gujarathi M \& Srinivasan G (1980), "Shareholders Discount Coupons - A Case of Disguised Dividends", Chartered Accountant, Vol. 27, No. 9, March, p. 833-36.

LXXX.Gujarathi M. (1981), "Performance of New Equity Shares: An Indian Experience", Doctoral Dissertation, Indian Institute of Management, Ahmedabad.

LXXXI.Gujarathi Mahendra (1987), "Do New Equity Issues fetch Extranormal Returns?", Vikalpa, Vol. 12, No. 4 (Oct-Dec), p. 43-50.

LXXXII.Gupta L C (1978), "Bonus Shares: Facts, Fiction \& Policy", Chartered Accountant, Vol. 27, No 2, p 85-90.

LXXXIII.Gupta L C (1980), "Long Term Rates of Return on Industrial Equities in India", Economic \& Political Weekly, Review of Management, August, p. M85-92.

LXXXIV.Gupta L C (1981), Rates of Return on Equities: The Indian Experience, Oxford University, press, New Delhi.

LXXXV.Gupta L C (1987), Shareholders Survey : Geographic Distrubution, Manas Publications, Delhi., p. 86.

LXXXVI.Gupta L C (1991), Indian Shareholders : A Survey, Society for Capital Market Research and Development, Delhi, p. 174.

LXXXVII.Gupta L C (1992), Stock Exchange Trading in India : Agenda for Reform, Society for Capital Market Research and Development, Delhi, p. 123.

LXXXVIII.Gupta O P (1980), "A Case for Convertible Debenture" Chartered Secretary, Vol 10, No. 5, (May), p. 464-466.

LXXXIX.Gupta O P (1985), Behaviour of Share Prices in India: A Test of Market Efficiency, National, New Delhi.

XC. Gupta O P (1989), Stock Market Efficiency and Price Behaviour (The Indian Experience), Anmol Publications, New Delhi, p. 373.

XCI. Gupta Ramesh (1978), "Fiscal Implications of Price Level Changes and Investment Decisions", Working Paper No. 214,(Apr-Jun), Indian Institute of Management. Ahmedabad.

XCII. Gupta Ramesh (1987), "Is the Indian Capital Market Inefficient of Excessively Speculative?", Vikalpa, Vol. 12, No. 2,(Apr-Jun), p. 21-28.

XCIII. Gupta Ramesh (1991a), "Revamping Stock Exchange Operations - Some Suggestions", Working Paper No. 922, (Jan-Mar), Indian Institute of Management, Ahmedabad.

XCIV. Gupta Ramesh (1991b), "Portfolio Management : The Process and Its Dynamics", Working Paper No. 923, (Jan-Mar), The Indian Institute of Management, Ahmedabad. 
XCV. Gupta Ramesh (1991c), "Regulation of Securities Market in India: Some Issues ", Chartered Secretary, Vol. 21, No. 6 (Jun).

XCVI. Gupta Ramesh (1992a), "Development of the Capital Market in India: A Regulatory Perspective", Working Paper No. 997, (Jan-Mar), Indian Institute of Management, Ahmedabad.

XCVII. Gupta Ramesh (1992), "Foreign Stock Listing: Benefits and Costs", Chartered Secretary, Vol. 22, No. 5 (May), p. 410-11.

XCVIII.Gupta Ramesh (1992), "Options Trading: A Primer and a Proposal", Chartered Secretary, Vol. 22, No. 10 (Oct), p. 883.

XCIX. Gupta S M (1991), "Behavioural Practices of Bonus Issues", Chartered Accountant, Vol 39, No. 12, p 1010.

C. $\quad$ Hingorani N L (1978), "Value of Rights Shares", Prajnan, Vol. VII, No. 4 (Oct-Dec), p. 359367.

CI. Ignatius Roger (1992), "The Bombay Stock Exchange : Seasonalities and Investment Oppurtunities", Indian Economic Review, Vol. XXVII, No. 2,p. 223-227.

CII. Jain P K (1979), "UTI \& The New Issue Market", Artha Vijnana, Vol. 21, No. 2 (June), p. 218.

CIII. Jain P K (1983), Financial Institutions of India: A Study of UTI, Triveni Publications, New Delhi.

CIV. Jhamb Mahendra (1991), "Mutual Funds Dominate Market Capital", Yojana, Vol. 35, July 15, p. 8-9.

CV. Kapadia M B (1981), "Financing with Convertible Debentures", Management Accountant, Vol. 16, No. 11, (Nov), p. 534.

CVI. Kapoor R C (1981), "Convertible Debentures : Major Financial Considerations", Management Accountant, Vol. 16, No. 7, (Jul), p. 321.

CVII. Kejriwal S R (1978), "Reservation of shares for Financial Institutions", Chartered Secretary, Vol. 8, No. 6 (Jun), p. 188-189.

CVIII. Kothari Rajesh (1986), "Profile of Recent Developments in Indian Capital Market", Prashanika, HCM-RIPA, Vol. XV, No. 4 (Oct-Dec).

CIX. Khan M Y (1977), "New Issue Market and Company Finance", Economic \& Political Weekly, Review of Management, Vol. 12, p. M11-21.

CX. Khan M.Y. (1978), New Issues Market and Finance for Industry in India, Allied Publishers, Bombay, p 149. 
CXI. Kulkarni N Suresh (1978), "Share Price Behaviour in India : A Spectral Analysis of Random Walk Hypothesis", Sankhya, The Indian Journal of Statistics, Vol. 40, Series D, p. 135-162.

CXII. Lal Jawahar (1992), "Investors' Understanding of Information: Some Evidence", Chartered Secretary, Vol. 22, No. 3 (Mar), p. 211.

CXIII. Lal T (1990), "Primary Capital Market : Some Reflections", Yojana, Vol. 34, June 16-30, p. 9-12.

CXIV. Mahapatra R P \& Sahu P K (1993), "A Note on Determinants of Corporate Dividend Behaviour in India - an Econometric Analysis", Decision, Vol. 20 (1), p. 1-22.

CXV. Mayya M R (1977), "Do Equities Act as a Hedge against Inflation?", Economic \& Political Weekly, Review of Management, Vol. 12, (May), p. M61-71.

CXVI. Mayya M R (1978), "Do Stock Exchanges have a Future?", Economic \& Political Weekly, Review of Management, (Feb) Vol. 13, p. M19-25.

CXVII. Mazumdar H (1959), Business Investment in India, J.B. Walters Publishing Co. Cromington.

CXVIII.Mehta Nipun S (1992), OTC Exchange of India : The Stock Exchange for You and Me, Jaico Publishers, Bombay.

CXIX. Mookerjee Raju (1988), "The Stock Market and The Economy : The Indian Experience", Indian Economic Journal, Vol. 36 No. 2 (Oct-Dec), p. 30-43.

CXX. Nachane D M (1988), "The Interest-Price Nexus : An Old Theme Revisited", Economic \& Political Weekly, Vol. 23, Feb.27, p. 421-424.

CXXI. Narayanaswamy R (1989), "Capital Market Efficiency and Financial Reporting", IIMB Management Review, Vol. 4 No. 2, p. 55-69

CXXII. Obaidullah M (1991), "The PricelEarnings Ratio Anomaly in Indian Stock Markets", Decision, Vol 18 (Jul-Sep), p 183.

CXXIII.Obaidullah M (1992), "How do Stock Prices React to Bonus Issues?", Vikalpa, Vol. 17, No. 1 (Jan-Mar), p. 17-22.

CXXIV.Ojha Raj P (1973), "Corporate Dividend Policy in India Cotton Textile Industry", University of Rajasthan, 1973.

CXXV. Palaha Satinder (1991), Cost of Capital and Corporate, policy, with Special Reference to the Influence of Changes in Accounting Variables on Stock Prices, Anmol Publications, New Delhi, p 186.

CXXVI.Pandey I M (1981), Capital Structure and the Cost of Capital, Vikas, New Delhi.

CXXVII.Pandya V H (1992), "Securities and Exchange Board of India: Its Role, Powers, Functions and Activities", Chartered Secretary, Vol. 22, No. 9 (Sept), p. 783. 
CXXVIII.Pasricha S.N. (1979), "Fixed Investment Behaviour in India - A Survey of Econometric Studies", Margin, Vol 12, p 115-130.

CXXIX.Patil R H (1987), "Can the Stock Exchanges Support the Envisaged Capital Growth?", Vikalpa, Vol. 12, No. 3,(Jul-Sept), p. 31-43.

CXXX.Prabhakaran Malathy (1989), "Do Equities Act as a Hedge against Inflation?", Economic \& Political Weekly, Vol. 24, No. 8, Feb 25, p. 24-26.

CXXXI.Premchander (1989), "Protecting Debentureholders in the Capital Market", Vikalpa, Vol. 14,No. (Jan-Mar), p. 43-46.

CXXXII.Puranik Alok (1992), "Role of Corporate Securities in Household Saving and Private Corporate Sector Financing during Eighties - Some Empirical Observations", Chartered Secretary, Vol. 22, No. 11 (Nov), p. 991.

CXXXIII.Purnanandam J \& Hanumantha Rao K.S. (1966), "Corporate Dividends and Target, payout Ratios in the Indian Cotton Textile Industry 1946-1963", Journal of Industrial Economics, Vol XV. No. 1,(Nov), p 38-43.

CXXXIV.Rafat Mubeen (1990), "Critical Factors Influencing Financing Decisions: Regulatory Framework", ASCI Journal of Management, Vol. 20, No. 2-3 (Sept-Dec).

CXXXV.Raghunathan V \& Srinivasan G (1985), "Investment Oppurtunities and Gordon's Stock Valuation model - A Note", Working Paper No. 588, (Oct-Dec), Indian Institute of Management, Ahmedabad.

CXXXVI.Raghunathan V \& Srinivasan G (1987), "Target Debt Maintanence Under Alternative Net Present Value Specifications and Implications for Investment and Finance Decisions", Working Paper No. 669, (Apr-Jun), Indian Institute of Management, Ahmedabad.

CXXXVII.Raghunathan V (1991), Stock Exchanges and Investments: Straight Answers to 100 Nagging Questions, Tata McGraw Hill, New Delhi, p. 176.

CXXXVIII.Raghunathan V \& Varma J R (1991), "Market Valuation Model Under Differential Taxes, Inflation, Recurring Investments and Flotation Costs", Working Paper No. 956, (JulSep), Indian Institute of Management, Ahmedabad.

CXXXIX.Raghunathan V, Varma J R \& Venkiteswaran N (1991), "The New Economic Package and the Agenda for the Restructuring the Financial Sector (Perspectives)", Vikalpa, Vol. 16, No. 3 (Jul-Sep), p. 3-11.

CXL. Raghunathan V \& Varma J R (1992a), "Why the Dollars do not Flow into India", Unpublished Paper, Indian Institute of Management, Ahmedabad.

CXLI. Raghunathan V \& Varma J R (1992b), "Crisil Rating : When Does AAA mean B?", Vikalpa, Vol. 17, No. 2 (Apr-Jun), p. 35-42.

CXLII. Raghunathan V \& Varma J R (1993), "When AAA Means B: The State of Credit Rating In India", Working Paper No. 1141, Indian Institute of Management, Ahmedabad. 
CXLIII.Ramachandran G (1989), "Behaviour of Share Prices - A Statistical Analysis", Doctoral Dissertation, Institute for Financial Management and Research.

CXLIV.Ramachandran G (1992), "Information Content of Bonus Issues - An Empirical Analysis in the Indian Context", Working Paper Series, January, Unit Trust of India.

CXLV.Ramachandran J (1985), "Behaviour of Stock Market Prices, Trading Rules, Information \& Market Efficiency", Doctoral Dissertation, Indian Institute of Management, Ahmedabad.

CXLVI.Ramachandran K S (1993), Scanning the Scam: How and Why of the Securities Scandal, NEO Publishing Company, New Delhi, p. 199.

CXLVII.Ram Mohan T T (1980), "Equity Issues by New Units -, patterns of Public Response", Economic \& Political Weekly, Review of Management, Vol. 15,(Nov), p. M151-156.

CXLVIII.Ranganatham M \& Subramanian V (1993), "Weak Form of Efficient Markets Hypothesis : A Spectral Analytical Investigation", Vikalpa, Vol. 18, No. 2 (Apr-Jun)

CXLIX.Rao Narayana K V S S \& Bhole L M (1990), "Inflation and Equity Returns", Economic \& Political Weekly, Vol. 25, No. 21, May 26, p. M 91-96.

CL. Ravishankar D., "The Indian Stock Market Mechanism - Badla Rates and its Implications", Unpublished Paper, UTI Institute of Capital Markets.

CLI. Saha A (1988), "Merchant Banking : Retrospect \& Prospects", Yojana, Vol XVII, No 1, 1988, p 61-79.

CLII. Sahni S K (1985), Stock Exchanges in India: Practices, Problems, Prospects, North Publishing Corporation, New Delhi, p 344.

CLIII. Sahu R K (1992), "A Critical Review of the Mutual Fund Regulations", Chartered Secretary, Vol. 22, No. 12 (Dec), p. 1076.

CLIV. Sankar T L, Mishra R K and Nandagopal R (1992), "Credit Rating: A New Concept in Security Analysis in India", Chartered Secretary, Vol. 22, No. 5 (May), p. 412-415.

CLV. Sankaran Venkateshwar (1991), "The Relationship of Indian Stock Market to Other Stock Markets", Indian Economic Journal, Vol. 39, No. 2 (Oct-Dec), p. 105-109.

CLVI. Sarma S Narasimha (1993), Financial Economics of Bonus Shares: Implications for the Value of the Firm, Academic Foundation, Delhi., p 144.

CLVII. Saroja S (1992), Emerging Trends in the Capital Market in India, Global Business Press, New Delhi.

CLVIII.Sastry V K (1966), "Dividends, Investments and External Financing Behaviour of the Corporate Sector of India", Doctoral Dissertation, University of Pennsylvania. 
CLIX. Sen T M \& Chandrashekar C (1986), All About Debentures, Wadhwa \& Company, Allahabad.

CLX. Sharma J L \& Kennedy R E (1977), "A Comparative Analysis of Stock Price Behaviour on the Bombay, London and New York Stock Exchanges", Journal of Financial \& Quantitative Analysis, Vol. 12, (Sept), p 319-414.

CLXI. Sharma J L (1983), "Efficient Capital Markets \& Random Character of Stock Prices Behaviour in a Developing Economy", Indian Journal of Economics, Vol. 63, No. 251 (OctDec), p. 395.

CLXII. Sinha Sidharth (1992), "The High Price-Earnings Ratio in the Indian Stock Market and Investment by Foreign Financial Institutions", Unpublished Paper, Indian Institute of Management, Ahmedabad.

CLXIII.Sinha Sidharth (1993), "The Badla Market and Futures and Options", Unpublished Paper, Indian Institute of Management, Ahmedabad (pending presentation in CBOT Fifth Annual Asia-Pacific Futures Research Symposium, March 14/15, 1994, Taipei).

CLXIV.Simha S L N, Hemalatha D \& Balakrishnan S (1979), Investment Management, Institute of Financial Management and Research, Madras.

CLXV. Singh Preeti (1986), Investment Management : Security Analysis and Portfolio Management, Himalaya Publishing, Bombay, p. 579.

CLXVI.Singh Sukhdev (1990), "Convertible Debentures - An Increasing Trend", Chartered Secretary, Vol. XX, No. 8 (Aug), p. 644.

CLXVII.Sinha N, p (1983), "Convertible Debentures - An Analytical Study", Chartered Accountant, Vol. 31, No. 3 (Sept), p. 222.

CLXVIII.Srinivas Akella R \& Greenbaum Stuart I (1992), "Innovations in Interest Rates, Duration Transformation and Bank Stock Returns", Journal of Money, Credit \& Banking, Vol. 24(1), p. 24-42.

CLXIX.Srinivasan N P \& Narasimhan M S (1988), "Testing Stock Market Efficiency using Riskreturn Parity Rule (Notes \& Comments)", Vikalpa, Vol. 13, (Apr-Jun), p. 61-66.

CLXX.Srinivasan S. (1988), "Testing of Capital Assets, pricing Model in Indian Environment", Decision, Vol 15, (Jan-Mar), p. 51.

CLXXI.Srinivasan S, Mohapatra P K J \& Sahu K C (1988), "Understanding Short-run Stock Price Movements through System Dynamics", Decision, Vol 15, No. 1 (Jan-Mar).

CLXXII.Srinivasan R (1993) "Security Prices Behaviour Associated with Rights Issue-Related Events", Doctoral Dissertation, Indian Institute of Management, Ahmedabad.

CLXXIII.Srivastava R M (1984), "Testing Modigliani - Millers Dividend Valuation Model in Indian Context - A Case Study of 327 Joint Stock Companies", Management Accountant, Vol. 19, No. 11, (Nov), p. 641-642. 
CLXXIV.Srivastava R M (1991), "Merchant Banking In India - A Bright Future", Yojana, Vol. 35, May 15, p. 12-13.

CLXXV.Subramaniam S. (1989), "The Impact of Political and Economic Events on Stock Behaviour", Doctoral Dissertation, Indian Institute of Management, Ahmedabad.

CLXXVI.Subrahmanayam Y (1977), "Role of Preference Shares in the Indian Corporate Sector", Economic \& Political Weekly, Review of Management, Vol. 12, (Nov), p. M125-141.

CLXXVII.Sundaram S M (1991), "Soaring Stock Prices", Economic \& Political Weekly, Vol. 26, No. 18, May 4, p. 1184.

CLXXVIII.Trikha Kapil (1989), "Merchant Bankers \& Public Issues", Chartered Accountant, Vol. 38, No. 6 (Dec), p. 477.

CLXXIX.Varma J R (1988), "Asset Pricing Models Under Parameter Non-Stationarity", Doctoral Dissertation, Indian Institute of Management, Ahmedabad.

CLXXX.Varma J R \& Barua S K (1988), "Estimation Errors and Time Varying Betas in Event Studies - A New Approach", Working Paper No. 759, (Jul-Sept), Indian Institute of Management, Ahmedabad.

CLXXXI.Varma J R (1989), "Equilibrium Pricing of Special Bearer Bonds", Working Paper No. 817, (Jul-Sept), Indian Institute of Management, Ahmedabad.

CLXXXII.Varma J R \& Venkiteswaran N (1990), "Guidelines on Share Valuation : How Fair is Fair Value?", Vikalpa, Vol. 15, No. 4 (Oct-Dec), p. 3-10.

CLXXXIII.Varma J R (1991), "Is the BSE Sensitive Index Better than the National Index?", Working Paper No. 988, (Oct-Dec), Indian Institute of Management, Ahmedabad.

CLXXXIV.Varma J R, Raghunathan, Korwar A \& Bhatt M C (1992a), "The Narasimham Committee Report - Some Future Ramifications and Suggestions", Working Paper No. 1009, (Jan-Mar), Indian Institute of Management, Ahmedabad.

CLXXXV.Varma J R, Raghunathan V \& Bhatt M C (1992), "Comments on SEBI's Draft Takeover Code", Working Paper No. 1010, (Jan-Mar), Indian Institute of Management, Ahmedabad.

CLXXXVI.Verma J C (1990), Merchant Banking : Organisation and Management, Tata McGraw Hill, New Delhi, p. 354.

CLXXXVII.Vidhyashankar S (1990), "Mutual Funds - Emerging Trends in India", Chartered Secretary, Vol. XX, No. 8 (Aug), p. 639.

CLXXXVIII.Venugopalan S (1992), "Mutual Funds", Chartered Secretary, Vol. 22, No. 8 (Aug), p. 691.

CLXXXIX.Yalawar Y B (1988), "Bombay Stock Exchange : Rates of Return and Efficiency", Indian Economic Journal, Vol. 35, No. 4 (Apr-Jun), p. 68-121. 
CXC. Yasaswy N J (1985), Equity Investment Strategy, Tata McGraw Hill, New Delhi.

CXCI. Yasaswy N J (1991), Growth Stocks, Vision Books, New Delhi, p. 208.

CXCII. Yasaswy N J (1992a), Emerging Blue Chips : 1992-93 With Model Portfolios of the 177 Highfliers of the Year, Vision Books, New Delhi, p. 223.

CXCIII.Yasaswy N J (1992b), PSU Stocks Picking the Winners, Vision Books, New Delhi, p. 206.

CXCIV.Zahir M A \& Khanna Yakesh (1982), "Determinants of Stock Prices in India", Chartered Accountant, Vol. 30, No. 8 (Feb).

CXCV.Zahir M A (1992), "Factors Affecting Equity Prices in India", Chartered Accountant, Vol. XL, No. 9, p. 743-748. 